\title{
Experiences of Female Commercial Sex Workers in Marabastad, Pretoria
}

\author{
O. W. Letlape ${ }^{1} \&$ M. Dube ${ }^{1}$ \\ ${ }^{1}$ Department of Social Work, Lifestyle Diseases Entity, Faculty of Health Sciences, North-West University \\ (Mafikeng Campus), South Africa
}

Correspondence: Misheck Dube, North-West University (Mafikeng Campus), P. Bag X2046, 2735, South Africa. Tel: 27-183-892-983. E-mail: Misheckdube@gmail.com; Misheck.Dube@nwu.ac.za

Received: August 1, 2019 Accepted: September 28, 2019 Online Published: October 10, 2019

doi:10.5539/gjhs.v11n12p121 URL: https://doi.org/10.5539/gjhs.v11n12p121

\begin{abstract}
This paper discusses critically the experiences of the female commercial sex workers in Marabastad, Pretoria in South Africa. Even though commercial sex work is illegal in South Africa, evidence suggests that some women practice it owing to various factors and an investigative analysis of engaging in such an illegal activity in South Africa needs thorough investigation. This paper aims at providing synthesis on the bio-psychosocial benefits and risks of commercial sex work for women involved in it. A qualitative research approach was adopted which purposely interviewed nine women who practised commercial sex work in Marabastad. Due to secrecy in commercial sex work, snowball sampling was also employed to ensure that only women involved in the practice would be accessed to reach data saturation point for the study. Data were analysed thematically to capture the experiences of women. The findings showed that even though women practise commercial sex work in Marabastad, risks are more experienced than the benefits. Unpleasant life circumstances were revealed as the most compelling reasons women practised commercial sex work despite the inevitable bio-psychosocial consequences. This paper recommends various multi-sectorial approaches to ameliorate the consequences experienced by women practicing commercial sex work in Marabastad in South Africa.
\end{abstract}

Keywords: commercial sex work, South Africa, bio-psychosocial problems, women, health

\section{Introduction}

Despite being the oldest frowned upon practice since human history, prostitution as it was widely known has always been a taboo industry in the many parts of the world associated with lack of morals and self-respect to women practising it. In the $21^{\text {st }}$ century, commercial sex work it is still operational and it is known to be at its peak (Qayyum, Iqbal, Akhtar Hayat, Mehmood, \& Tabassum, 2013). Research has shown that there are approximately 45 million prostitutes in the world and $75 \%$ of them are aged between 13-25 years (Goldmann, 2011). India, for example, has more than 100000 commercial sex workers found in the only six metropolitan cities. The Netherlands and Germany in the late 1990s introduced new legislation to legalise prostitution to enable commercial sex workers to work as service providers (Schulze, Canto, Manson, \& Skalin, 2014). Commercial sex work happens in various avenues such as the streets and where it is legalised it happens in organised activities such as brothels. While some people view commercial sex work as a social problem, others view it as a job creation and as a way of earning income. Estimates show that commercial sex work revenue can be estimated to be roughly $\$ 186.00$ billion per year worldwide (Schulze et al., 2014). Although statistics can be difficult to compile due to the illegal nature of sex work in South Africa, research shows that during the 2010 FIFA World Cup, commercial sex workers in South Africa made approximately 1500 to 5000 South African rands per evening in income (Foundation Scelles, 2012).

As illegal as it is in the country and criminalised by the Sexual Offences Act (No 23 of 1957) and the Criminal Law Amendment Act (No.32 of 2007) of South Africa, commercial sex work is still operating in many areas with many commercial sex workers still seen in the streets and corners of Marabastad in Pretoria. Nowadays commercial sex workers use web-based applications to advertise themselves as well as to show their availability in this fourth industrial revolution era. It is not a secret also that the industry is growing in South Africa with the advent of new terms such as "blesser" and "blessee" (Mampane, 2018), to exonerate the industry and provide biblical connotations to persuade the South African Society to accept commercial sex work as not sinful. As much as there 
are risks and benefits of commercial sex work, research should also reveal the many factors leading to commercial sex work. This paper will highlight the risks and benefits of commercial sex work as well as the factors that lead to commercial sex work.

\subsection{Conceptual Clarity and the South African Context}

The debate and voices on commercial sex work and the circumstances in which it happens has brought afore many definitions and terms even though the act is the same. Those advocating that commercial sex work as an exploitative industry use the term "prostituted women" while those that perceive it as a source of income use the term "sex workers". Social media advocating for young women exchanging sex work with older men in South Africa use the terms "blesser" for a man having sex with young girls for money and gifts and "blessee" for a young girl receiving money and gifts in exchange for sex with an older man (Mampane, 2018).

In this study, the term commercial sex worker is used as the researchers are convinced that this is an objective term befitting a study of this nature whereas other terms (prostituted woman and blessee), are more inclined to subjective voices such as advocacy groups and social media moralists. Despite different terminologies used and befitting the circumstances and situations, commercial sex work is "conceived of as an act, practice or profession of offering the body for sexual relations in exchange for money" (New Webster's Dictionary, 2010, p. 802 as cited by Olofinbiyi, Mkhize, Dlamini, Maluleke, \& Olofinbiyi, 2019). Pudifin and Bosch (2012) cited Section 1 of the Sexual Offences Act of South Africa (No. 23 of 1957) which defines prostitution for the term commercial sex work as "the exchange of carnal intercourse, or acts of indecency for reward". A more befitting definition especially in the South African context is that of Pudifin and Bosch (2012) that commercial sex work is "the exchange of any financial or other reward, favour or compensation for the purpose of engaging in a sexual act". This definition is used in this paper as it covers all circumstances and situations in which commercial sex work is done. This study is mindful of the complexity of commercial sex work in South Africa such as gays and lesbians who are also engaged in commercial sex work. However the paper focuses on women practising sex work in Marabastad in Pretoria as they constituted $90 \%$ of the population practising commercial sex work in South Africa (Sonke Gender Justice, 2014). Commercial sex work is illegal in the country, however in 2017, the South African Law Reform Commission released a report in relation to adult commercial work which was to review the legislation framework that regulates adult commercial sex work. The main debate of the report was to discuss whether adult commercial work should be decriminalized fully or partial and to end prohibition as was the wish of the sex work advocates (South African Law Reform, 2017).

\subsection{Statement of the Problem}

Notwithstanding the fact that it is illegal and a taboo in South Africa, commercial sex work is a popular industry in the country practised in many corners owing to different circumstances and situations. Estimates show that about 182000 commercial sex workers exist in South Africa with the possibility that these figures can be higher (Rangasami, Konstant, \& Manoek, 2016). The debate on legalisation of commercial sex work in the country is inconclusive spiralling desperate clandestine commercial sex work activities in many places in South Africa especially Marabastad in Pretoria. Marabastad is a decaying part of Pretoria with a lot of economic activities ranging from legal to illegal. It is a place where thieves, merchants, traditional healers and sex workers feel comfortable to do their jobs. Whether legalised or illegal, commercial sex work has been fingered to be always a violent business of those involved (Gleich, 2017; Pennsylvania Coalition Against Rape, 2013). In Port Elizabeth in South Africa, $60 \%$ of women practising commercial sex work have been publicly verbally assaulted (Mac AIDS, 2015) and stigmatised (Prakash, 2013). Police have also contributed to violence against commercial sex work with $47 \%$ of women having been violently treated by the police (Rangasami et al., 2016). Women trafficking is common and made an astounding $95 \%$ of the problems in commercial sex work in 2012 (Goldmann, 2011; Foundation Scelles, 2012; Qayyum et al., 2013). An arsenal of problems have been also experienced in commercial sex work such as lack of payment, coerced sex, refusing use of condoms by clients, physical abuse such as pinching, slapping and threats with dangerous objects such as knifes or guns are also common in commercial sex work (Decker, Pearson, Illangasekare, Clark, \& Sherman, 2013).

Research has established involuntary entry into commercial sex work by women usually dating back from young age of exposure to violence (Pennsylvania Coalition Against Rape, 2013). Its legalisation or not has not been proven by research to reduce the bio-psychosocial consequences for women. The rhetoric of legalisation of commercial sex work in South Africa has been seen as a political and human rights issue with numerous moral questions from the South African public known for its fervent adherence to Christian ethos with the practice militating against human dignity (Malherbe, 2018). However research was needed to establish the lived experiences of women in commercial sex work in Marabastad, hence this study. 


\subsection{Aim of the Study}

The aim of the study was to determine the experiences of women on the benefits and risks of commercial sex work in Marabastad in Pretoria, South Africa.

\section{Theoretical Framework}

There are a number of theories which can explain the causes and implications of commercial sex work. In this study, the Social Dis-organisation theory and the feminist theory have been significant and influential and seen as more relevant to the study of commercial sex work in Marabastad.

\subsection{Social Dis-organisation Theory}

Social dis-organisation occurs when set of society's expectations fail. According to social disorganization theory, neighbourhood characteristics such as poverty and ethnic diversity causes higher crime. The emergence of social disorganisations occurs in three ways, when rules are missing, when there are contradictory rules and when conformity to rules is not rewarded or punished (Inderbitzin, Bates, \& Gainey, 2016). Social disorganisation can explain how problematic factors can lead to more problems. For example, Social Dis-organisation theorists contend that poverty and family problems can lead to commercial sex work for women (Michigan, 2015).

\subsection{Feminism Theory}

According to Teater (2014) feminism advocates for women's rights and seeks to address specific issues underpinning ways of understanding women. In most cases women are lead into commercial sex work more than men hence the theory of feminism is essential in this study to understand women. There are different feminism opinions regarding prostitution, whether women are victims and should be protected or whether women should be considered free agents pursuing their legitimate economic interest (O'Neill, 2013). Prostitution and feminism is about creating a platform for women's voices to be heard in order to understand the lived experiences of women working as commercial sex work.

Feminists argue that women working as commercial sex work are exploited by those who are in charge of the sex industry in modern societies, (O'Neill, 2013), despite the fact that women may circumstantially choose to be commercial sex workers. A gruelling argument according to O’Neill (2013) is that feminists air that commercial sex workers should not be blamed instead men who visit and organise them into prostitution should be held responsible. However not all feminists have the same view on commercial sex work. Two types of feminists are at odds in their arguments on commercial sex work with the sex-positive feminists advocating for sexual agencies for commercial sex workers while the camp of stop feminists advocating against commercial sex work due to moral agendas. They argue that selling sex should not be allowed due to the fact that a person's sexuality is an integral part of human life and part of identify (O'Neill, 2013). These hold interesting positions pertinent to this paper's discussions.

\section{Factors Contributing to Commercial Sex Work}

Several factors have been associated with engaging in commercial sex work by women. The main and leading factors have been linked to poverty and lack of jobs among the women population. In the debates and research studies, social, psychological, biological and religious factors are also dominant. However, this paper holds that the tussle to conclusively cement and exclusively label these factors in social sciences needs further and rigorous research due to the overly changing dynamics of human life over space and time.

\subsection{Economic Causes}

Both Prakash (2013) and Qayyum et al., (2013) have discovered that many women are led into commercial sex work because of economic factors that have been associated with impoverishing their lives. An arsenal of factors that have been linked to commercial sex work among women include lack of employment including underage employment, unhealthy working conditions and immoral trafficking of women and children (Prakash, 2013). Such factors are associated with a general lack of job related skills among women in South Africa owing to historical disadvantageous policies where many Black people were excluded from the proper education system. Further the current educational system demands financial well-up families with those less fortunate excluded which has fuelled the much documented strikes in the institutions of higher learning in the country (EduConnect, 2015). Not only women of South African origin are engaged in commercial sex work. Women from neighbouring countries such as Zimbabwe where soaring economic woes continue to displace them across the continent whether as documented or illegal migrants have been forced into commercial sex work in South Africa especially in Marabastad where the environment is ripe to engage in commercial sex work. This was evident also during the 2010 world cup hosted in South Africa (Foundation Scelles, 2012). 


\subsection{Social Causes}

Social issues comprise of family causes including parents clashes which can force young girls to run away from home into commercial sex work, (Qayyum et al., 2013). Young girls can also be forced into early marriages that often fail. Unpleasant social circumstances in the families such as divorces, domestic violence, broken marriages and lack of love to the girl child by their family can lead them into commercial sex work unintentionally (Prakash, 2013). Also bad neighbourhood where there is gangsterism practice, existence of brothels and slum life are fertile grounds for commercial sex work (Qayyum et al., 2013). Social interaction is seen as crucial in influencing girls to become commercial sex workers. Cementing on this argument, Kangiwa (2015), for example contends that girls become sex workers through interaction with other sex workers.

\subsection{Psychological Causes}

Most women who are frigid or in other words "cold" are lead into commercial sex work (Prakash, 2013). Although Prakash (2013) did not go into the entire range of psychological factors, but argues that such frigid women often try one man and another without sexual satisfaction and eventually become sex workers. Other possible psychological factors that are argued to lead women into the sex industry include trauma or sexual addiction even those economically affluent women and their customers. Research have also shown the existence of a relationship between sex work and psychological problems such as delinquent personality (Tiosavljević, Djukić-Dejanović, Turza, Jovanović, \& Jeremić, 2016).

\subsection{Biological Factors}

There are some persons born with defective sex organs or over-active glands that are compelled to seek sex in a taboo manner hence they run to the sex industry (Prakash, 2013). Some sexual disorders such as sexual addiction also have been linked to sexual promiscuity. Sexual addictions can incline women to commercial sex work (Psych Guides, 2017). In the view of Herkov (2016) sexual addicted persons have progressive intimacy disorder which has compulsive sexual thoughts and behaviours making them constantly in need of sex. Some people also with higher levels of sex hormones are most likely to partake in excessive sexual behaviours. Thus biological factors have an implication on commercial sex work among women.

\subsection{Religious and Cultural Factors}

Interestingly religious and cultural factors have been argued to have influence on commercial sex work contrary to the laymen view that religion and culture are expected to militate and question the morality of commercial sex work. Qayyum et al. (2013) stated that in the oldest days sex workers were found in temples and that women had to sleep with strangers who had the potential of becoming their husbands. Clearly some cultures and religions promote promiscuous sexual behaviours and see it as sacredness. In some Indian cultures for example, parents sell the virginity of their girls as an entrenched practice (Foundation Scelles, 2012). The Hindu practices "Devadasis" where sex work is done in temples although this practice is facing scrutiny (Foundation Scelles, 2012). Even though arguments on the intention sex work housed in temples and also sanctioned by cultural and religious practices saw the act as socially functional, the morality question remains fragile and tense with some scholars regarding commercial sex workers as morally immature (Tiosavljević et al., 2016).

\section{Problems Associated With Commercial Sex Work}

A crucial element of the act of commercial sex work is to analyse the problems associated with the practice. A cavalier of problems have been associated with commercial sex work. For the very fact that commercial sex work is a fragile and controversial subject which is striving and blooming at the expense of illegality and immorality questions in South Africa and many other countries has attracted a host of problems established by research which have dire bio-psychosocial implications for women. Various studies have revealed a conglomerate of problems associated with commercial sex work which present untold and enduring bio-psychosocial consequences in the lives of women including those close to them such as their children.

\subsection{Exploitation of Women}

Researchers such as Prakash (2013) have argued that commercial sex work does not exist without exploitation of women which at many times is an involuntary act spearheaded by socio-economic circumstances. Commercial sex work has been widely associated with the problem of women trafficking (Goldmann, 2011; Foundation Scelles, 2012). Qayyum et al. (2013) discovered that in most cases, pimps deceive young women by giving false assurance for a job and abduct them and eventually selling them in brothels aggravating exploitation of women. It has been noted for example that most young girls in South Africa are trafficked from rural areas into big cities for the promise of jobs. Women who have been exploited in South Africa through trafficking networks within the country 
and neighbouring countries made an astounding 95\% in 2012 (Foundation Scelles, 2012).

\subsection{Sexual Diseases Infections}

Sexual diseases have always had a slice on the problems experienced by women in sex work practice. Sexually transmitted diseases have contested the health space in the lives of women practising commercial sex work. Several researchers (Qayyum et al., 2013; Phrasisombath, Faxelid, Sychareun, \& Thomsen, 2012), all share the sentiment that women beleaguered worse and severe health consequences like contacting many sexually transmitted infections including the Human Immune Virus (HIV) and Acquired Immune Deficiency Syndrome (AIDS). Prakash (2013) also stated how commercial sex work is related to the spread of venereal diseases because commercial sex workers do not always practice safe sex as prices paid for a commercial sex worker's services are higher when a condom is not used. All modes of sexual gratification, oral anal and vaginal intercourse have been found to present avenues for the spread of sexually transmitted infections (Phrasisombath et al., 2012). Commercial sex workers are not the only people at risk of contracting diseases. Even their customers and their children are at a high risk of getting infected with sexually transmitted diseases.

\subsection{Abuse of Women}

The commercial sex industry has been also found to be abusive to women. Some clients of the sex workers are aggressive and sometimes physically assault them. In addition, abuse such as lack of payment, coerced sex, rejecting the use of condoms, pinching, slapping and threats with dangerous objects such as knifes or guns have been revealed by research to be common in the commercial sex industry (Decker et al., 2013). Other women experience rape and snatching of belongings and money (Phrasisombath et al., 2012) which has innumerable psychosocial consequences.

\subsection{Stigmatisation}

Commercial sex work is a quick and easy way to earn money and is arguably stigmatised to be an open occupation to helpless and debased women who want to earn a living. Kangiwa (2015) maintains a critical approach purporting that prostitution is evil and poses a threat to the moral standards of societies with high levels of stigma (Richter \& Chakuvinga, 2012). In South Africa for example, a study in Port Elizabeth revealed that $60 \%$ of sex workers reported having been publicly verbally assaulted and abused. The stigma has been attached and extended to their innocent children (Mac AIDS, 2015).

\subsection{Arrests by Police}

In the views of people who are not prostitutes, police seem to be law abiding citizens and responsible to maintaining law and order. This has not been synonymous with the lived experiences of commercial sex workers in South Africa. The question of the legality and morality around commercial sex work has opened protection rifts and barriers and catalysed abuse of many women practising sex work without recourse. Rangasami et al. (2016) have noted statistics in a survey by Gould and Fick (2008) that $47 \%$ of sex workers reported being threatened by police with violence, $12 \%$ reported having been raped by police, and $28 \%$ had been asked for sex by policemen in exchange for release from custody in South Africa.

\subsection{Psychological Problems}

Commercial sex work has been associated with psychological problems for women. Many women practising it have been alleged to use two personalities with one being the sex worker personality while the other being the private personality through the conscious use of fake names and wearing makeup resulting into disassociation (Goldmann, 2011; Tiosavljević, et al., 2016). Serious psychological issues such as depression, suicidal tendencies, panic attacks, traumatic stress, trouble sleeping, flash backs, and migraines have been found to be associated with commercial sex work (Edwards \& Verona, 2016; Goldmann, 2011).

\section{Benefits of Commercial Sex Work}

Another school of thought has provided arguments for the benefits of commercial sex work. Despite the fact that it has been labelled evil and a psychological disorder, the benefits lens has a different perspective purporting that it has recognisable benefits and should be decriminalised (Bacchi, 2018; News24, 2018).

\subsection{Financial Benefits}

Financial benefits have been always associated with commercial sex work. This has been also the crux of the argument for those who see it as evil arguing that selling a woman's body for financial benefits is immoral. One special argument is that women in commercial sex work make sufficient income to take care of themselves and their families. For both employed and unemployed sex workers, the practice makes it easy for women to make 
money, (Phrasisombath et al., 2012), and the amount of money made from customers has significantly improved their financial position. It is also evident that some poor living conditions of women have landed them into commercial sex work to help ease the poor living conditions in their homes. Some researchers have argued that if regulated, even the governments can raise significant revenue, (David \& Odeku, 2017), arguing for example that brothels make heft sums of money that can be taxed.

\subsection{Sexual Gratification}

Researchers such as Phrasisombath et al., (2012) have found that some have sexual gratification in commercial sex work especially with handsome clients. Some commercial sex workers revealed not having sexual gratification before being commercial sex workers (Gander, 2016). This signifies that actually commercial sex workers also have sexual pleasure with some clients. Against this finding, it was noted that the more time a commercial sex worker spends in reaching climax to enjoy sex, the more time wasted to make enough income.

\section{Research Methodology}

A qualitative research approach was adopted in this study, (Hennink, Hunter, \& Baily, 2011), to gather the first-hand experiences of commercial sex workers in Marabastad in Pretoria. This enabled gathering in-depth information on the experiences of the commercial sex workers who participated in the study.

\subsection{Population and Sampling}

All adult commercial sex workers in Marabastad constituted possible participants in this study and hence formed the population (Taherdoost, 2016) from which the sample was drawn. A homogenous sample of nine female commercial sex workers were involved in the study using non-probability purposive and snowball techniques (Denscombe 2010; Gray, 2014). Purposive sampling enabled the inclusion of only adult commercial sex in Marabastad on the basis of their experience in the practice of commercial sex work rather than mere chance of inclusion (Denscombe, 2010). Criminalisation of commercial sex work in South Africa makes it difficult to for commercial sex workers to freely come out and participate in the study for fear of arrests and hence snowball sampling was used to allow identified commercial sex workers to link the researcher to those they know to practise it in their own circles (Tracy, 2013). This enabled the researcher to access more participants for the study until data saturation point where new information in the interviews could not emerge (Gray, 2014).

\subsection{Instrumentation and Data Collection}

Data in this study were collected using an interview schedule, (Kothari, 2014), prepared for the interviews arranged with the participants of the study. Prompts were used by the researcher collecting data on particular themes of the questions to enable participants to share as much as possible about their experiences facilitating the researcher understanding and to have insight about the participants' experiences (Dube, 2016). Data were collected from nine participants of the study using in-depth one-on-one interviews during the evening when commercial sex workers are at work. Nine participants enabled the researcher responsible for interviewing to reach data saturation point. Padgett (2017) suggests that when determining the sample size, a smaller number is desirable for collection of intense information to enable intensity and homogeneity. Padgett (2017) suggests that the researcher needs to go "an inch wide and a mile deep," suggesting that a smaller number is desirable for collection of intense information in a qualitative study. This study engaged nine participants in in-depth interviews collecting sufficient data for the purposes of this study. Of the nine participants, two were interviewed in the streets of Marabastad while seven were interviewed in a brothel. The information on how to access more participants was gained through snowballing from the first two participants. One researcher was responsible for interviewing the participants while the other observed at a distance to provide safety to the researcher conducting interviews as the interviews were done in the evening when commercial sex workers are at work. This paper agrees with the views of Dube (2016) citing Stinger (2014 p.105) that one-on-one interviews enables the participant to engage in a "reflective process" and "explore his or her experience in detail and reveal the many features of that experience..." which this study intended to achieve. This is congruent with the feminist theory which influenced this study. Data were audio-recorded so that the researcher could not miss and part of the essential information in the interview processes.

\subsection{Data Analysis}

As in the perspective of Kothari (2014) who contends that data analysis occurs after its collection, in this study, categories were developed according to the themes and emerging themes to create order to the processed data and make meaning out of it. The analysis of data followed six categories that included becoming familiar with the data, generating initial codes, searching for themes, reviewing the themes, defining and naming the themes, and then producing the research report (Braun \& Clarke, 2006 as cited by Maguire \& Delahunt, 2017; Clarke \& Braun, 
2013). The audio-recorded interviews were transcribed verbatim by the researcher through listening to each of the nine audio-recorded interviews to get the meaning from their articulated stories. Following the six categories of the data analysis process, this then led to data reduction and filtering the information (Hennink et al., 2011).

\subsection{Ethical Considerations}

The topic of prostitution remains a very sensitive and contentious issues embedded with moral judgments and illegal in South Africa. As such it was befitting for the researchers in this study to observe relevant ethical issues. The researcher thus had to ensure that the participants remain anonymous, (Hennink et al., 2011), to avoid labelling and victimisation. To this end the identifying information of the participants could not be solicited from the participants. Pseudonyms were also used instead of real names, (Denscombe, 2010), of the participants in the study.

The researchers also ensured that participation was entirely voluntary and the participants were told that withdrawal from the study had no penalties (Stinger, 2014). Due to the emotional nature of the study, questions that had the potential to be highly emotional were used sparingly and the researchers had pre-arranged counselling for the participants (Dube, 2016).

\section{Findings}

The findings of the study centred on the aim of the study to which was to determine the experiences of women on the benefits and risks of commercial sex work in Marabastad in Pretoria. To that end, the discussion on the findings of the study are thematically analysed with verbatim information from the participants. This created an analytical perspective that is backed by exiting literature.

\subsection{Factors That Led Participants Into Commercial Sex Work}

The participants were asked questions about circumstances that led them into commercial sex work and how they ended up in the profession. Prominent among their responses that made themes for discussion included poverty, drug addiction, parental issues and marriage problems. It was also common among the participants that in some instances, there were more than one reason that was revealed in the interviews to have been influential for participants to be engaged in commercial sex work.

\subsubsection{Poverty}

One reason that emerged during the interviews with the participants was poverty. All the nine participants highlighted some elements of poverty in their lives that influenced their decisions to be commercial sex workers. For them poverty generally is equated to the inability to meet the basic needs and those of their children. During the interviews these were the common areas of concern for the participants. Below are their responses.

"I am only doing this job because of poverty, I cannot afford food in the house so I have to do this to afford and I am a single parent. My son also goes to college." - Tendai.

"I decided to go into sex work because I am poor, so through this job I am getting out of poverty. I apply for jobs everywhere and I do not get any responses and I am tired of that so at least here I get money fast to buy bread"Lucy.

"The father of my child does not support the child so the main reason I do this is to also support my child, he even left me."- Teneli.

From the findings of the study, the economic reasons emerged evidently as the main reason why women participated in commercial sex work. Poverty from their interpretation is lack of adequate economic resources to meet their everyday demands to life. Similarly, Mampane, (2018), Prakash (2013) and Qayyum et al. (2013) have discovered in their research that economic resources were at the heart of the causes of sex work for women. The Social Dis-organisation theorists such as Inderbitzin et al., (2016) have also reiterated the connection between poverty and commercial sex work asserting that poverty causes disorganisation and problems in the lives of people therefore act as a catalyst for other social problems such as sex work and crime. One important subtheme in this finding was that many of those who fail to meet their needs have been found to be single parents. This signifies the fact that single parenting adds to the burden that women have about their lives therefore sacrificing their lives into commercial sex work to meet the needs of the extra burden of caring for their children. With the increasing number of single parents and job scarcity in South Africa, (Fourie, 2018), it means that commercial sex work has favourable foundation and fertile ground to remain a growing industry. Fourie (2018) found that $60 \%$ of South African children have an absent father and $40 \%$ of the women are single mothers. This lays the foundation for the claim that commercial sex work is likely to be on the rise in South Africa owing to economic problems emanating from single parenthood. 


\subsubsection{Drug Addiction}

Drug addictions were health reasons synonymous with the findings of this study. Some participants had more than just poverty driving them into commercial sex work. It emerged that some participants needed to meet the costs of drugs to feed their cravings. Dada, Harker, Laubscher, Parry and Myers (2018) have observed that fewer women reported have been addicted to other drugs in the Western Cape due to the taboo associated with females being drug addicts as drugs are associated with antisocial behaviour such as sex work. Their findings documented that women are then forced to shy away from reporting that they are drug addicts. In this study there were only two participants who disclosed and had this to say:

"I am smoking Nyaope so I sleep with men just to get money for this drug and I cannot find a proper job because of my drug addiction."- Teneli.

“...I also use drugs so at least with the money I get from customers I can be able to buy drugs. ”- Lucy.

The findings of this study resonates with the findings of other researchers, (Prakash, 2013; National Institutes on Drug Abuse, 2014; South African Law Reform Commission, 2017), who have reiterated the connection between drug and sex addiction and commercial sex work. Classified as a biological factor, drug and sex addiction are seen as diseases as they change the brain and affects the hierarchy of needs and desires necessitating over involvement in sexual activities which results into sex work (National Institute on Drug Abuse, 2014). The study of the South African Law Reform Commission (2017) also suggests that commercial sex workers use drugs to hide the embarrassment of being sex workers. This paper posits that drug use in commercial sex work can therefore be seen as a defence mechanism used to subvert the conscious moral issues and questions around commercial sex work and maintain the irrational and immorality argued to surround the practice of sex work.

\subsubsection{Parental Issues}

As a contributor to numerous psychosocial problems in girl children, problematic family background were found to play a big role in determining whether women can be commercial sex workers. In the families, poor parenting emerged to be a factor that can lead children into sex work when they grow up. All of the nine participants in the study had problematic childhood upbringing. The family support system is evidently important during the development of girls as the family provides the needed support for proper development of children. The participants were asked about their families as a support system and the issue of poor parenting emerged in the study. Below are some of the responses of the participants:

"My parents never cared for me; my mother was an alcohol addict. If my family cared for me I wouldn't be doing this job." - Selina.

"...I do not have any family support. My parents are also poor, my family is filled with poverty that is the other reason why I do this job because there is nobody I can run to." - Nolitha.

"I grew up in an abusive family. My mother does not even know what I am doing now. She never cared for me." Lee.

"My mother was supportive however she died when I was still young so I had no support, my father ran away from us."'- Tendai.

"I don't think my aunt whom I grown up in her family loved me",-Thelma.

The study found that most commercial sex workers come from dysfunctional families and a very significant factor in determining the practice of sex work among participants in Marabastad. All the participants had problematic childhood parenting backgrounds and recounted that it was one of the reasons they befell commercial sex workers. The Social Dis-organisation theory argues that such disorganisation in families is in itself a problem that causes other psychosocial problems in the family and hence children can resort to sex work and other criminal activities (Inderbitzin et al., (2016). The study shows that failure of family systems to nurture the girl children can cause psychosocial social problems and may lead them into sex work. According to Qayyum et al. (2013) social issues in families that need to be checked include parental clashes, parents who may run away from home and abandon their own children and abusive parents. These compromise proper development of children and predispose them to immoral activities such as a life of crime and commercial sex work.

\subsubsection{Marriage}

Failed and problematic marriages play a significant role in psychosocial problems among women and have also been found to influence the practice of commercial sex work. Some failed and problematic marriages offer fertile grounds for women engaging in divorce and separation and intense emotions therefore making women vulnerable 
to commercial sex work in Marabastad. Though not all the participants have once experienced marriage, but two of the nine participants raised problematic and failed marriages as significant issues that propelled practising commercial sex work. Abuse of women (physical, emotional, financial among others) is one important element that has led many marriages to fail and hence the fragile nature of women leaves them without an option but to opt out of the marriages (Prakash, 2013). Currently in South Africa, there are shocking statistics showing an increase of $64 \%$ in divorces from the years of 2009-2017 with the highest divorce rates being among the Black population (Statistics South Africa, 2019). The increase in failed marriages could denote a likelihood of an increase in commercial sex workers in South Africa in general. This theme emerged in the study and some participants revealed the following:

"I was married before but the man was abusive, he would come home and beat me. I do not think he loved me and he was not supporting his children financially. I was just emotionally hurt and it used to stress me a lot."- Lee.

"I was in an abusive marriage before I decided to this job. That man would not buy food in the house; he would not support our child and he had a good job." -Teneli.

\subsection{The Benefits Associated With Commercial Sex Work}

In the study, participants also provided their personal experiences on the benefits they get from commercial sex work. Their responses in this regard resonated on economic and psychosocial issues. As analysed, the main themes in this section remain confined to money, solving drug addictions and the solving psychosocial problems. The study however, did not gather much evidence of the benefits of commercial sex work in Marabastad.

\subsubsection{Financial Benefits}

All the nice participants' responses resoundingly revolved on economic issues as their financial positions cannot meet the basic needs in the household. Despite the fact that some participants have other sources of income, family responsibilities makes the income they receive inadequate to meet their needs. For one participant this is what her experience was:

"I am a single parent and the child support grant is not enough to take care of my three children plus my grandchildren and they have to go to school again so prostitution is the solution to my problem."- Lee.

Other researchers have also highlighted financial benefits for those engaged in commercial sex work (Phrasisombath et al., 2012). The researchers advocating for decriminalisation of commercial sex work argued that the South African government is missing out on possible revenue generation if commercial sex work can be legalised and tax collected as a source of revenue (David \& Odeku, 2017). The financial benefits associated with commercial sex work weigh against the fact that some clients may not pay and abuse sex workers while others ask for unprotected sex for them to pay more for the services they received from the sex workers. The stop feminist however, discourage selling of sex in exchange of money. They allege that selling sex is a violation of a person's sexuality as an integral part of human life and part of identify (O'Neill, 2013). The financial benefits of commercial sex work seem to be achieved with a certain level of considerable danger and discomfort to the commercial sex workers.

\subsubsection{As a Way of Addressing Drug Addiction}

The study also found out that women practice sex work because they have been addicted to drugs which they need to take consistently (Prakash, 2013; National Institute on Drug Abuse, 2014; South African Law Reform Commission, 2017). Drugs create cravings which people who are addicted to them need to compulsively take. Some participants in the study revealed that commercial sex work helps them find money to buy drugs to feed their cravings created by addiction. This is what they revealed:

"I am smoking Nyaope so I sleep with men just to get money for this drug.....because of my drug addiction."Teneli.

\section{“...I also use drugs so at least....I can be able to buy drugs."'- Lucy.}

In essence some commercial sex workers have a problem of addiction to drugs and hence they resort to prostitution as a quicker way of raising money to buy drugs and deal with the compulsive urge to take the drugs. This in itself is trying to solve one problem with another which creates a tangle of issues for them. Taking of drugs by women practising commercial sex work has also lowered their abilities to negotiate safe sex with their clients and predisposes them to a host of sexually transmitted infections (Decker at al, 2013; Phrasisombath et al., 2012). The stop feminist have argued that this in itself has moral questions for women and air that such practices need to stop to restore women's dignity (O'Neill, 2013). 


\subsubsection{Solving Psychosocial Problems}

Sometimes commercial sex workers are engulfed by intense psychosocial issues that need to be dealt with. These issues many range from family problems and a failed or problematic marriage. For the girl child, before she practices sex work, it could be the feeling of lack of love from the family. To gain independence and solve these problems, (Sonke Gender Justice, 2014), a girl or a woman finds that the possible way to solving these psychosocial problems is through practising commercial sex work. One participant revealed her psychosocial ordeal that she thought commercial sex helped to manage:

"I grew up without parents and my relatives who were there never cared about me, they were abusive. That is why I even decided to do this job......."- Tamara.

\subsection{The Risks Associated With Commercial Sex Work}

The study also sought to find out the risks associated with commercial sex work from the views of the participants in the study. This paper revealed lived experiences of women practising commercial sex work in Marabastad which are also consistent with the feminist theories to which this study was committed. An arsenal of the bio-psychosocial risks were disclosed by the participants which are consequential to their lives.

\subsubsection{Negotiating Condom Use}

The most and prominent risk for women practising commercial sex work was negotiating condom use. From the people not practising commercial sex work, it might seem to be a farfetched reality that condom use negotiation is difficult for sex workers, yet it is the most difficult reality for them. According to the South African Law Reform Commission (2017) most commercial sex workers underscore the fact that most men expect sex without a condom. Further, when the condom is not used during sexual intercourse, sex workers are paid more than when there is the use of the condom. To maximise income from commercial sex work, women are easily lured into agreeing to sex without a condom (South African Law Reform Commission, 2017). Feminists have argued that such acts from men are abusive and need to stop as they undermine the freedom and dignity of women (Teater, 2014). In the study, all the nine participants revealed the difficulty in negotiating condom use during business with their clients. Below are some of the sensitive responses of five participants who experienced the challenge of condom use:

“...sometimes clients force us to sleep with them without condoms even when you tell them you have condoms, they refuse. I prevent unwanted pregnancies; I use the loop."-Thelma.

"I do not protect most of the time because the clients would promise to pay more without condom and sometimes they say they do not love condoms but they know about HIV/AIDS..."- Vella.

"I am on contraceptives to prevent pregnancies and sometimes I would be too high and drunk to remember condoms, so I do not use condoms at times. Some customers do not want to use condoms anyway."-Teneli.

"Even though I want to use protection but I can attest that most prostitutes like myself have been forced by customers to not use condom. The customers do not like condoms even when you open up about your status." -Lee.

"I use protection but I remember last year I got a customer who said he does not want to use protection and I just slept with him because I wanted the money."'-Tendai.

The health risks are many in commercial sex work. The revelations by the participants are testimonial to the eminent health risks involved with many customers' demand for forceful unprotected sex (Decker at al, 2013). In some instances women practising commercial sex work have been physically abused, forced into some form of sex acts that were not initially agreed upon with their clients. Even in instances where condoms could be provided for free, women in prostitution are always at a risk of sex without a condom predisposing them to contracting HIV/AIDS and many forms of dangerous STIs (Phrasisombath et al., 2012). Substance abuse cannot be over ruled in safe sex negotiations. Sometimes commercial sex workers fail to negotiate condom use due to the fact that they will be high on drugs or drunk to make proper decisions.

\subsubsection{Health Challenges}

A host of health challenges have been reportedly an issue with commercial sex work in Marabastad. Emanating from the failure to successfully negotiating safe sex with their clients, contracting sexually transmitted diseases has been reportedly inevitable. Mampane, (2012), Phrasisombath et al., (2012) and Qayyum et al., (2013) emphasised the risk of contracting HIV/AIDS and many other sexually transmitted illnesses. These diseases are sexually transmitted by clients who do not want to use protection (South African Law Reform Commission, 2017). In the study, the participants reported that they have had sexual transmitted infections at one stage and some of them opened up that they have contracted HIV/AIDS. Below are the reports of the five participants with regards to their 
health challenges:

"I am already having HIV/AIDS but it is not the end of the world, I sometimes tell the customers about my status but [aahhh] they still do not want condom."- Lee.

"I remember last year I had an STD, I think it was syphilis." - Teneli.

"...I had sores and pains around my genitals I might have got it from one of the customers because I told you they do not love condoms." -Tamara.

"I thank God I am not HIV/AIDS positive but I once had an STI because this job I am doing is risky."-Tendai.

"I have not yet contracted HIV/AIDS but I had an infection, what can I say..." -Lucy.

This study revealed the evident risk of some life time and chronic illness being part of the life of the commercial sex workers in Marabastad. In the analysis of the information provided by the participants, proper management of health and medical expenses pause as a strain for the prostitutes who also need to be functionally healthy to be able to attract the clients and be able to generate income. A compromised health of a commercial sex worker will be unattractive to the clients and then adversely affect the business which reduces income drastically and may drive the commercial sex worker out of the industry.

\subsubsection{Abuse}

The psychosocial problems are eminent as commercial sex workers often suffer physical and financial abuse from their clients. They also suffer deterioration due to loss of dignity and the stigma that is attached to the practice of commercial sex work (Rangasami, et al., 2016; Prakash, 2013). Instead of protecting the sex workers, police officers have been on record in perpetrating violence and secondary victimisation (The South African Law Reform Commission, 2017). All the nine participants in the study have experienced abuse of some kind from the police and their clients which contributes negatively to their psychosocial well-being and unfortunately adding to a host of psychosocial struggles (Goldmann, 2011; Tiosavljević, et al., 2016). Below are some of the experiences revealed by the participants:

"I remember during 2010 World Cup, the police came to me here in Pretoria. They started swearing at me and asked me to give them money or they would arrest me and then I refused and then they forced me to sleep with them."-Tamara.

"...the police do not take us serious when we report rape or assault because we are prostitutes." - Lucy.

"Customers refuse to pay sometimes after sleeping with them and I remember the other time a customer beat me after I told him to pay. [Yoh] It is stressing because we cannot even report this matters to the police because they do not take us serious themselves. "- Lee.

"People do not take us serious, the clients do not pay sometimes and they would make us do most inhuman things when having sex. They make us do sex styles we don't even know." - Teneli.

"I have experienced a customer beating me and not being gentle when having sex with me. Sometimes the customers would not want to pay and make threats after receiving the service."- Tendai.

The abuse suffered from commercial sex work have adverse psychosocial health implications that cannot be ignored. Besides being abused, the sex workers cannot access support and protection they need due to the illegal nature of the practice in South Africa. The circle of abuse remains stifling as professional support is scanty if it does not exist at all. For these reasons, sex-positive feminist have always been advocating for sex agents to help protect women practising commercial sex work (O'Neill, 2013). We maintain in this paper that commercial sex workers are at higher risks of having psychological disorders, physical harm or even death.

\section{Limitations of the Study}

The study on commercial sex work in South Africa has limitations embedded in them. The practice of commercial sex work is illegal in the country and therefore accessing sex workers to engage them in the study has been difficult. They fear arrest from law enforcement agents and hence would find it difficult to trust any suspicious stranger who wants to talk to them for fear of arrest. Notwithstanding that, snowball sampling helped in accessing the number of participants who were interviewed in a brothel to achieve data saturation point for the study. Women practising commercial sex work themselves were of help to the researcher in identifying other participants in the study.

Women practising commercial sex work are very conscious about time spending. It was not easy to keep them on the interviews for longer times as they panicked and felt that they were wasting time they could have used to get money from their clients. The participants however, were able to answer all questions despite the fact they mostly 
gave short answers.

\section{Discussion of Findings}

The discussion of the findings fall into two main categories. The discussion will centre on the findings of the lived experiences of women in Marabastad who practice commercial sex work in order to draw relevant and sound conclusions and recommendations.

\subsection{Benefits of Commercial Sex}

The discussion of the research findings relate to the personal experiences of the women practising commercial sex work in Marabastad. From the findings of the study and as a point of departure, women enter into commercial sex work involuntarily. It emerged that surrounding their choice to be sex workers, several factors are at play and they have little control over them. These factors also serve as the benefits of commercial sex work for women and influence their decisions to engage in sex work. The main driving force towards commercial sex work in Marabastad is the need for financial security similar to the findings by (Phrasisombath et al., 2012). All the nine participants in the study practice commercial sex work for the need to raise income for survival. This is one major benefit the participants highlighted in the interviews. It underscores that financial pressures are the main cause for women practising commercial sex work. The souring economy and rising cost of living in South Africa has made some all the participants to practice commercial work to meet the financial demands of life for themselves and their families. With the rising cost of living and loss of jobs and the weakening of the South African economy, commercial sex work is likely to thrive despite the fact that it is illegal. The reality is that women would be forced to meet their financial needs and hence we deduce that commercial sex activities with thrive in South Africa. This means that commercial sex work will continue to be practised in Marabastad despite the eminent bio-psychosocial risks of the practice as established by researchers (Mampane, 2012; Phrasisombath et al., 2012; Prakash, 2013; Qayyum et al., 2013; Rangasami, et al., 2016; The South African Law Reform Commission, 2017).

The scourge of drugs in Marabastad and in South Africa in general is astonishing. Some participants engage in commercial sex work because of addiction to drugs such as Nyaope common in the streets of Pretoria. Drug addiction creates cravings that women want to satisfy. Again here the practice of commercial sex work is involuntary. The drugs change the way the brain works and an urge to take drugs is catalysed in the nervous system which then forces women into commercial sex work to meet the expenses of the drugs. Even though some women practising sex work may not be entirely addicted, the use of drugs takes away the feelings and embarrassment of being a commercial sex worker. These reasons also serve as benefits of sex work.

It emerged also that some painful circumstances such as a failed marriages and painful childhood background and upbringing of the girl child can force them to become commercial sex workers when they grow up. This confirms the position of the Social Dis-organisation theory which argues that disorganisation in families is a problem that causes other psychosocial problems in the family and hence children can resort to sex work and other criminal activities (Inderbitzin et al., (2016). Some participants deliberated on painful home circumstances and for those who were once married, failed marriages have been factors. Commercial sex work then gives them autonomy and freedom they normally yean for.

\subsection{Risks Associated With Commercial Sex Work}

Not only does commercial sex work present benefits, it is also a risky practice for women. Risks that this study managed to gather include inability for women to negotiate safe sex and a change in mind of their clients once the agreement has been reached. Some clients also refuse to pay and sometimes physically assault the prostitutes. This renders women practising commercial sex work vulnerable most of the time. The bitterest part of commercial sex work is that the law segregates sex workers and it is still illegal in South Africa. This means in other words when commercial sex workers are abused, they cannot access legal recourse. Rather, they face secondary victimisation from law enforcement agents such as the police (The South African Law Reform Commission, 2017). The women practising commercial sex work have to find ways of avoiding arrests such as bribing the police and even offering sex to them. Moral judgments are also attached to the practice of commercial sex work making it more difficult for women to even seek counselling. This compounds the bio-psychosocial problems associated with commercial sex work to the detriment of the women.

Health risks are eminent. The practice of unsafe sex fuelled by the need to get more money from the clients when they do not use condoms as well as arrogance of some clients pause as a serious issue in Marabastad sex workers. Some participants revealed having contracted the STIs and sometimes HIV/AIDS (Mampane, 2012). The costs in managing proper health with the rising costs of healthy living is a reality for the commercial sex workers. Sex workers are then forced to take extra health care yet they cannot afford the basic needs of their lives. This becomes 
a daunting task and a near impossibility. The drug addiction associated with commercial sex work is a profound health risk. The physical effects of drugs can present illnesses for women practising sex work when addicted.

The debate of the benefits and risks associated with commercial sex work is evidently far from over. Apparent from the findings of this study, commercial sex work has not offered as much of the benefits as the narrative has. This study has gathered evidence that shows more risks associated with commercial sex than the benefits. Even the benefits highlighted are also punctuated by serious bio-psychosocial health consequences for women.

\section{Conclusions}

Several conclusions have been reached and made from the data analysed in the study on the experiences of women in commercial sex work in Marabastad. The information has been analysed and synthesised to draw conclusions from the lived personal experiences of the women commercial sex work.

This study concludes that women enter into commercial sex work involuntarily. Psychosocial pain is one struggle that has forced women into commercial sex work emanating from forced circumstances surrounding them which they seemingly have no control over. Some of the involuntary circumstances stretch as far as childhood within families and others a result of experiences in adulthood, for example failed marriages and were unfortunately not well dealt with. This evidently from the study participants have serious psychosocial implications rendering women into commercial sex work.

The study also concludes that commercial sex work is mainly sustained by financial benefits paid to the women by their clients. Some other smaller benefits include feeding the cravings of drug addiction and also it serves as a mechanism that gives women autonomy over their lives especially women who have experienced abuse from home and marriages.

This study also concludes that inevitable risks involved in commercial sex work are more pronounced that the benefits accrued from the practice. Commercial sex work is heavily characterised by bio-psychosocial risks which pause as threats to the lives of the sex workers.

\section{Recommendations}

Bearing in mind that most women engage in commercial sex work to get income, it is therefore recommended that social workers should assist women with empowerment based projects to ameliorate some of the circumstances that force women into commercial sex work. This will go a long way to engage women in income generating projects to provide supplementary income needed to meet the needs and demands of their lives and families. This may counteract the need to engage in commercial sex work to meet the pressing financial needs.

It can be recommended that the government departments and the NGO sector empower women through tailor-made gender-based programmes for dealing with women abuse related matters. Support networks can be created to allow peer and personalised interventions for women.

The risks involved in commercial sex work denote the need to protect commercial sex work through health, psychosocial, educational and legal instruments to ensure their inclusion into the mainstream social welfare without oppression, prejudice and exclusion. There is need to change legal and policy frameworks to ensure legally protected sex work and sanction deliberate health, social and educational programmes for commercial sex workers' protection and well-being.

\section{Competing Interests Statement}

The authors declare that there are no competing or potential conflicts of interest.

\section{References}

Bacchi, U. (2018). Legalizing prostitution lowers violence and disease, report says. Retrieved from https://www.reuters.com/article/us-global-women-prostitution/legalizing-prostitution-lowers-violence-and-d isease-report-says-idUSKBN1OA28N.

Balfour, R., \& Allen, J. (2014). A Review of Literature on Sex Workers and Social Exclusion. UCL Institute of Health Equity. Retrieved from https://assets.publishing.service.gov.uk/government/uploads/ system/uploads/attachment_data/file/303927/A_Review_of_the_Literature_on_sex_workers_and_social_ex clusion.pdf

Clarke, V., \& Braun, V. (2013). Teaching thematic analysis: Overcoming challenges and developing strategies for effective learning. The Psychologist, 26(2), 120-123. Retrieved from http://eprints.uwe.ac.uk/21155.

Dada, S., Burnhams, H. N., Laubscher, R., Parry, C., \& Myers B. (2018). Alcohol and other drug use among 
women seeking substance abuse treatment in the Western Cape, South Africa. South African Journal of Science, 114(9/10), 1-7. https://doi.org/10.17159/sajs.2018/4451

David, M. M., \& Odeku, K. O. (2017). Revenues and Taxes from Sex Work: A critical perspective. Gender \& Behaviour, 15(3), 9691-9707. Retrieved from https://www.ajol.info/index.php/gab/article/view/165580

Decker, M. R., Pearson, E., Illangasekare, S. L., Clark, E., \& Sherman, S. G. (2013). Violence against women in sex work and HIV risk implications differ qualitatively by perpetrator. https://doi.org/10.1186/1471-2458-13-876

Denscombe, M. (2010). The Good Research Guide for Small-Scale Social Research Projects (4th ed). London: McGraw Hill.

Dube, M. (2016). The psycho-social plight of widows in Binga District in Zimbabwe: the efficacy of social work intervention (Thesis-PhD). Mafikeng: North West University. Retrieved from http:/hdl.handle.net/10394/24924

EduConnect. (2015). Fees Must Fall - South Africa's 2015 Student Protest. Retrieved from https://educonnect.co.za/fees-must-fall-south-africas-2015-student-protest/

Edwards, B. G., \& Verona, E. (2016). Gendered contexts: psychopathy and drug use in relation to sex work and exchange. Journal of Abnormal Psychology, 125(4), 514-527. https://doi.org/10.1037/abn0000159

Foundation Scelles. (2012). Sexual Exploitation, Prostitution and Organised Crimes. Paris. Foundation Scelles. Retrieved from https://www.fondationscelles.org/pdf/rapport_mondial/sexual_exploitation_prostitution_ Fondation_Scelles.pdf

Fourie, J. (2018). Why are there so many single mothers? Retrieved from https://www.fin24.com/Finweek/Opinion/why-are-there-so-many-single-mothers-20180926.

Gander, K. (2016). How sex workers encounter pleasure with clients. Retrieved from https://www.independent.co.uk/life-style/love-sex/sex-worker-pleasure-with-clients-prostitution-gratificatio n-intimacy-a 7484056.html

Gleich, L. (2017). Prostitution and violence against women. Retrieved from https://www.care.org.uk/news/latest-news/prostitution-and-violence-against-women.

Goldmann, C. (2011). Current Assessment of the State of Prostitution: Recognise, Understand and Fight Sexual Exploitation (3rd ed). Foundation Scelles. Retrieved from https://www.fondationscelles.org/pdf/current-assessment-of-the-state-of-prostitution-2013.pdf.

Gray, D. E. (2014). Doing Research in the Real World. Los Angeles: Sage.

Hennink, M., Hunter, I., \& Bailey, A. (2011). Qualitative research methods. Los Angeles: Sage Publications.

Herkov, M. (2016). 'What is sexual addiction?' Psych Central. Retrieved from https://psychcentral.com/lib/what-is-sexual-addiction/

Inderbitzin, M., Bates, K. A., \& Gainey, R. R. (2016). Deviance and Social Control: A Sociological Perspective. Los Angeles: SAGE Publications.

Kangiwa, A. G. (2015). The socio-economic factors and effects of prostitution in Nigeria. European Journal of Research in Social Sciences, 3(5), 2056- 5429. Retrieved from https://www.idpublications.org/wp-content/uploads/2015/05/THE-SOCIO $\%$ E2\%80\%93ECONOMIC-FAC TORS-AND-EFFECTS-OF-PROSTITUTION-IN-NIGERIA.pdf

Kothari, C. R. (2014). Research Methodology: Methods and Techniques (2nd ed.). New Dheli: New Age International Publishers

Malherbe, R. (2018). Prostitution Violates Human Dignity. Retrieved from http://pinionproject.org/2018/prostitution-violates-human-dignity/

Mac AIDS. (2015). Prevention of Mother to Child Transmission Needs of Female Sex Workers Study. Mac AIDS Fund Research Brief. Retrieved from http://www.google.com/url?sa=t\&rct=j\&q=\&esrc=s\&source= web\&cd $=3 \& c a d=r j a \& u a c t=8 \& v e d=2$ ahUKEwjS6vend jaAhU0XRUIHZEnDzsQFjACegQIAxAC\&url=http $\% 3 \mathrm{~A} \% 2 \mathrm{~F} \% 2 \mathrm{Fwww}$.hsrc.ac.za\%2Fen\%2Fresearch-outputs\%2Fktree-doc\%2F15661\&usg=AOvVaw0j4E8o DfJGdjD7eoi4X_oe

Maguire, M., \& Delahunt, B. (2017). Doing a Thematic Analysis: A Practical, Step-by-Step Guide for Learning 
and Teaching Scholars. All Ireland Journal of Teaching and Learning in Higher Education, 8(5), 3351-33514. Retrieved from http://ojs.aishe.org/index.php/aishe-j/article/viewFile/335/553

Mampane, J. (2018). Exploring the "Blesser and Blessee" Phenomenon: Young Women, Transactional Sex, and HIV in Rural South Africa. SAGE Open, 8(4). https://doi.org/10.1177/2158244018806343

Michigan, A. A. (2015). The Link Between Prostitution and Poverty. Retrieved from https://www.borgenmagazine.com/prostitution-poverty/

National Institute on Drug Abuse. (2014). Drugs, Brains, and Behavior: The Science of Addiction. Retrieved from https://d14rmgtrwzf5a.cloudfront.net/sites/default/files/soa_2014.pdf

News24. (2018). Women do not choose prostitution, it chooses us. Retrieved from https://www.news24.com/Columnists/GuestColumn/women-do-not-choose-prostitution-it-chooses-us-2018 1128.

Olofinbiyi, S. A., Mkhize, S., Dlamini, S., Maluleke, W., \& Olofinbiyi, O. B. (2019). Social dimension of risk behaviours among adolescent prostitutes: Insight from South-Western Nigeria. Cogent Social Sciences. https://doi.org/10.1080/23311886.2019.1565616

O'Neill, M. (2013). Prostitution and Feminism: Towards a Politics of Feeling. New York: John Wiley \& Sons.

Padgett, D. K. (2017). Qualitative Methods in Social Work Research (3rd ed). Los Angeles: SAGE.

Pennsylvania Coalition Against Rape. (2013). The Intersection Between Prostitution and Sexual Violence. Pennsylvania: Pennsylvania Coalition Against Rape. Retrieved from

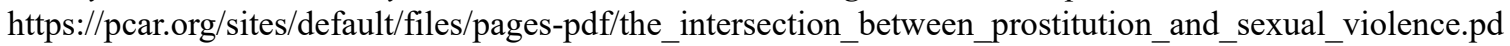
$\mathrm{f}$

Phrasisombath, K., Faxelid, E., Sychareun, V., \& Thomsen, S. (2012). Risks, benefits and survival strategies-views from female sex workers in Savannakhet, Laos. BMC Public Health. https://doi.org/10.1186/1471-2458-12-1004

Prakash, H. (2013). Prostitution and Its Impact on Society-A Criminological Perspective. International Research Journal of Social Science. 2(3), 31-39. Retrieved from https://pdfs.semanticscholar.org/4172/259028704aac5cb1e392233bcbf6f6ed2414.pdf.

Psych Guides. (2017). Sex Addiction symptoms, causes and effects. Retrieved from https://www.psychguides.com/behavioral-disorders/sex-addiction/

Pudifin, S., \& Bosch, S. (2012). Demographic and Social Factors Influencing Public Opinion On Prostitution: An Exploratory Study in KwaZulu-Natal Province, South Africa. PER/PEL, 15(4)1-39. https://doi.org/10.4314/pelj.v15i4.1

Qayyum, S., Iqbal, M. M. A., Akhtar, A., Hayat, A., Janjua, I. M., \& Tabassum, S. (2013). Causes and decision of women's involvement into prostitution and its consequences in Punjab, Pakistan. Academic Research International, 4(5), 398-411. $\quad$ Retrieved http://www.savap.org.pk/journals/ARInt./Vol.4(5)/2013(4.5-40).pdf

Rangasami, J., Konstant, T., \& Manoek, S. (2016). Police Abuse of Sex Workers: Data from cases reported to the Women's Legal Centre between 2011 and 2015. Women's Legal Centre. Retrieved from http://wlce.co.za/wp-content/uploads/2017/02/Police-abuse-of-sex-workers.pdf

Richter, M., \& Chakuvinga, P. (2012). Being pimped out - How South Africa's AIDS response fails sex workers. Agenda: Empowering women for gender equity, 26(2), 65-79. https://doi.org/10.1080/10130950.2012.704751

Ritchie, J., Lewis, J., Nicholls, C. M., \& Ormston, R. (2013). Qualitative Research Practice: A Guide for Social Science Students and Researchers. Los Angeles: SAGE Publishers

Schulze, E., Canto, S. I. N., Manson, P., \& Skalin, M. (2014). Sexual exploitation and prostitution and its impact on gender equality. Brussels: European Parliament Directorate-general for Internal Policies. Retrieved from http://www.europarl.europa.eu/RegData/etudes/etudes/join/2014/493040/IPOL-FEMM_ET(2014)493040_E N.pdf

Sonke Gender Justice. (2014). Sex Workers and Sex Work in South Africa - A Guide for Journalists andWriters. Cape Town: Sonke Gender Justice, Sisonke Sex Workers Movement, Sex Worker Education and Advocacy Task Force and Women's Legal Centre. Retrieved from 
https://genderjustice.org.za/publication/sex-workers-and-sex-work-in-south-africa/

South African Government. (1957). Sexual Offences Act of 1957. Retrieved from https://www.gov.za/documents/sexual-offences-act-previous-short-title-immorality-act-12-apr-1957-0000.

South African Government. (2007). Criminal Law Amendment Act of 2007. Retrieved from http://www.justice.gov.za/legislation/acts/2007-032.pdf

South African Law Reform Commission. (2017). Sexual offences: Adult prostitution. Retrieved from http://www.justice.gov.za/salrc/reports/r-pr107-SXO-AdultProstitution-2017-Sum.pdf

Statistics South Africa. (2019). Marriages and Divorces 2017. Pretoria. Statistics South Africa. Retrieved from http://www.divorcelaws.co.za/divorce-statistics.html

Stinger, E. T. (2014). Action research (4th ed). Los Angeles: SAGE Publications.

Teater, B. (2014). An Introduction to applying social work theories and methods. England: Open University Press.

Taherdoost, H. (2016). Sampling Methods in Research Methodology; How to Choose a Sampling Technique for Research. International Journal of Academic Research in Management, 5(2), 18-27. https://doi.org/10.2139/ssrn.3205035

Tiosavljević, D., Djukić-Dejanović, S., Turza, K., Jovanović, A., \& Jeremić, V. (2016). Prostitution as a Psychiatric situation: Ethical Aspects. Psychiatria Danubina, 28(4), 349-356. Retrieved from http://www.psychiatria-danubina.com/UserDocsImages/pdf/dnb_vol28_no4/dnb_vol28_no4_349.pdf

Tracy, S. J. (2013). Qualitative research methods: Collecting evidence, crafting analysis, communicating impact. Oxford: Wiley-Blackwell.

\section{Copyrights}

Copyright for this article is retained by the author(s), with first publication rights granted to the journal.

This is an open-access article distributed under the terms and conditions of the Creative Commons Attribution license (http://creativecommons.org/licenses/by/4.0/). 